\title{
Effects of non-steroidal growth implant and dietary zilpaterol hydrochloride on growth and carcass characteristics of feedlot lambs
}

\author{
E.C. Webb ${ }^{1 \#}$, J. Allen ${ }^{1}$ \& S.D. Morris ${ }^{2}$ \\ ${ }^{1}$ Department of Animal and Wildlife Science, University of Pretoria. Pretoria, South Africa \\ ${ }^{2}$ Private Feedlot Consultant \& Veterinarian, P.O. Box 53, Strathaven, 2031, South Africa
}

(Received 18 December 2017; Accepted 21 February 2018; First published online 3 April 2018)

\begin{abstract}
Copyright resides with the authors in terms of the Creative Commons Attribution 4.0 South African Licence.
See: http://creativecommons.org/licenses/by/4.0/za

Condition of use: The user may copy, distribute, transmit and adapt the work, but must recognise the authors and the South African Journal of Animal Science.
\end{abstract}

\begin{abstract}
The effects of steroidal growth implants alone or in combination with $\beta$-adrenergic agonist feed additives have not been studied thoroughly in mutton sheep in South African feedlot conditions. This study investigated the effects of a non-steroidal growth implant zeranol (Ralgro®), alone or in combination with zilpaterol hydrochloride (Zilmax®), on growth performance, carcass characteristics, and selected meat quality traits in $160 \mathrm{SA}$ Mutton Merino ram lambs fed in a commercial feedlot. The experimental design consisted of two Ralgro treatment groups $x$ two Zilmax treatments $x$ two Zilmax feeding periods $x 20$ animals per treatment group. Lambs were randomly allocated to eight treatment groups, of which one half were implanted with Ralgro after arrival, followed by feed supplementation with Zilmax at two Zilmax feeding periods during the finisher phase, compared with negative control treatments (e.g. no Ralgro or Zilmax; Ralgro + no Zilmax; or no Ralgro + Zilmax). All lambs were fed the grower ration traditionally used by the commercial feedlot, which contained $16.89 \%$ crude protein (CP) and $2.94 \mathrm{Mcal} / \mathrm{kg}$ dry matter (DM). Zilmax was supplemented in the feed at $40 \mathrm{mg}$ per animal per day and fed for 18 days or 25 days, plus three days withdrawal. Lambs that did not receive the Zilmax treatment were fed the basal diet without Zilmax feed supplementation. Ralgro significantly increased average daily gains (ADG) and cold carcass mass (CCM) of lambs. Lambs supplemented with Zilmax during the finisher phase had higher ADG, greater CCM and increased dressing percentage by ca.1.1\% compared with those in the control group. Lambs fed Zilmax for 25 days had higher CCM than those fed for 18 days. The duration of the Zilmax treatment also decreased hide weight, fat thickness and shear force values (tenderness). Zilmax increased ADG and CCM in lambs, particularly if combined with Ralgro implants during the growing phase. The results from this study indicate that the combination of Ralgro implants with Zilmax feed supplementation during the finisher phase had additive effects and increased ADG and CCM of feedlot lambs.
\end{abstract}

Keywords: Growth performance, meat quality, South African Mutton Merino, sheep, Ralgro®, Zilmax®

\#Corresponding author: Edward.webb@up.ac.za

\section{Introduction}

Zilpaterol hydrochloride (Zilmax $®$ ) is a beta-adrenergic agonist ( $\beta$-agonist) that is used commercially as Zilmax. It is a repartitioning agent and is utilized for its potential to promote growth (Ricks et al., 1984). Zilmax was registered for use in cattle in South Africa in 1995, and is employed commercially in Mexico and the USA (López-Carlos et al., 2011). $\beta$-agonists stimulate beta-adrenergic receptors on the cell surface, cause protein synthesis, and inhibit proteolysis, which promotes cell hyperplasia (Mersmann, 1998). The overall response is an increase in growth efficiency, making $\beta$-agonists an economical product to use (Courtheyn et al., 2002). The benefits of Zilmax supplementation in lambs are similar to those in beef, with increases in growth performance and carcass characteristics (Avendaño-Reyers et al., 2011; Estrada-Angulo et al., 2008; López-Carlos et al., 2011; López-Carlos et al., 2010). Zilmax is not yet available for use in the local mutton industry, and there are still inconsistencies in the effects, use, and efficacy of $\beta$-agonist supplementation and growth performance of feedlot lambs (Estrada-Angulo et al., 2008; López-Carlos et al., 2011; Nourozi et al., 2008).

Lamb and mutton were traditionally produced in extensive systems in South Africa, which did not warrant a fattening phase in the production process (Webb \& Erasmus, 2013). However, more producers are 
looking to an intensive fattening phase, owing to poor growth performance on extensive systems, unpredictable weather, stock theft and a demand for specific carcass grades. Sheep should respond well to $\beta$-agonist treatment since they fatten faster and contain considerably more carcass fat than cattle in South Africa (Webb \& O'Neill, 2008).

Combining Zilmax and growth-promoting implants is common practice for commercial beef producers. However, it has yet to be investigated in sheep. Research on the combination of steroidal implants and Zilmax in cattle yielded an additive effect (Baxa et al., 2010; Neill et al., 2009). Neill et al. (2009) stated that to realise the full potential of Zilmax, it may be necessary to implant the animal. Zeranol is a non-steroidal growth implant that is manufactured under the name Ralgro® (MSD Animal Health South Africa), which is commonly used in sheep. It is a resorcyclic acid lactone, which is an oestrogen-like compound that is found in corn mould Giberella zeae (Perry et al., 1970; Sharp \& Dyer, 1971). The objective of this study was to investigate the effects of a non-steroidal growth implant (Ralgro), alone or in combination with dietary Zilmax supplementation on growth and carcass characteristics of feedlot lambs.

\section{Materials and Methods}

A completely randomized control study was conducted to evaluate the effects of a non-steroidal exogenous growth implant zeranol (Ralgro), alone or in combination with Zilmax feed additive supplemented during the finishing phase on the growth, carcass, and selected meat quality parameters of mutton sheep fattened in typical feedlot conditions (Table 1). This project was approved by the Animal Ethics Committee of the University of Pretoria in 2015 (\#ec030-15).

One hundred and sixty intact SA Mutton Merino lambs of similar age and live mass and from the same breeder were selected at a commercial feedlot near Harrismith, South Africa. Lambs had already undergone the regular feed adaption period used by the feedlot. The initial mass of the lambs was ca. $31.69 \mathrm{~kg}$ and all had no permanent incisors. The experimental design consisted of two Ralgro treatment groups $x$ two Zilmax treatments $\times$ two Zilmax feeding periods x 20 animals per treatment group (Table 1). A total of 160 lambs of similar phenotype and weight were randomly allocated to one of eight treatment groups. Lambs were identified with ear tags, weighed, and vaccinated on arrival at the feedlot on day 1 (day 1 of trial) with Ovipast Plus® (MSD South Africa), Coglavax® (Ceva South Africa), Virbamax First Drench® (Virbac South Africa) and Prodose Yellow LA® (Virbac South Africa). Lambs randomly allocated to the Ralgro treatment groups were implanted with Ralgro (MSD South Africa) implants in their left ear. After 14 days of adaptation, all lambs received follow-up vaccinations of Multivax-P Plus (MSD South Africa) and Ovipast Plus ${ }^{\circledR}$ (MSD South Africa).

Table 1 Diagrammatic representation of the experimental design

\begin{tabular}{ccc}
\hline $\begin{array}{c}\text { Ralgro implant treatment } \\
\text { (Grower phase) }\end{array}$ & $\begin{array}{c}\text { Zilmax treatment } \\
\text { (Finisher phase) }\end{array}$ & Zilmax feeding period \\
\hline $\begin{array}{c}\text { Control group } \\
(\text { No Ralgro implant) } \\
(\mathrm{n}=80)\end{array}$ & Control $(\mathrm{n}=40)$ & 18 days $(\mathrm{n}=20)$ \\
& Zilmax $(\mathrm{n}=40)$ & 25 days $(\mathrm{n}=20)$ \\
& & 18 days $(\mathrm{n}=20)$ \\
& Control $(\mathrm{n}=40)$ & 25 days $(\mathrm{n}=20)$ \\
Ralgro implant & 18 days $(\mathrm{n}=20)$ \\
$(\mathrm{n}=80)$ & Zilmax $(\mathrm{n}=40)$ & 25 days $(\mathrm{n}=20)$ \\
& & 18 days $(\mathrm{n}=20)$ \\
& 25 days $(\mathrm{n}=20)$ \\
\hline
\end{tabular}

Lambs were randomly allocated to one of four pens consisting of 20 Ralgro implanted and 20 nonimplanted animals per pen, totalling 40 lambs per pen. Lambs were identified individually by colour-coded ear tags to differentiate among treatments, with odd numbers indicating the lambs implanted with Ralgro. All lambs were fed the same grower ration traditionally used by the commercial feedlot, which contained $16.89 \%$ $\mathrm{CP}$ and 2.94 Mcal/kg DM. During the finishing phase, Zilmax was included in the diet by dissolving it in molasses (Zilmol®). Lambs were fed the grower ration for 51 days, followed by 18 days or 25 days of Zilmax inclusion at $40 \mathrm{mg} / \mathrm{animal}$ per day in the finisher diets of lambs in the Zilmax treatment groups, and no Zilmax supplementation in the Zilmax control groups. Lambs received water and feed ad libitum. Empty 
bodyweights of lambs were recorded about $08 \mathrm{~h} 00$ at the commercial feedlot on day 1 after arrival (day 1), at the end of the growing phase (day 51), and before slaughter (day 72 or day 79 ). The ADG was calculated and recorded for individual lambs.

Lambs were slaughtered after a total feeding period of 72 days ( 51 days growing +18 days Zilmax +3 days withdrawal) or 79 days (51 days growing +25 days Zilmax +3 days withdrawal) at a registered commercial abattoir near Harrismith, South Africa. Hot carcass weight (HCW) was recorded immediately after dressing and removing the hide. The hide was weighed on an electronic scale and recorded. Postmortem inspection was done to document abnormalities. After cooling, the cold carcass weights (CCMs) were recorded and subcutaneous fat thickness was measured at a point over the 13th thoracic vertebra, approximately $5 \mathrm{~cm}$ from the medial line (Webb et al., 1994). Carcass $\mathrm{pH}$ was recorded at 45 minutes $\left(\mathrm{pH}_{45}\right)$ and 24 hours $\left(\mathrm{pH}_{\mathrm{u}}\right)$ post mortem by inserting a temperature-compensating meat-type $\mathrm{pH}$ electrode into the $m$. longissimus lumborum approximately $5 \mathrm{~cm}$ from the medial line at a point over the 13th thoracic vertebrae. Ten carcasses were randomly selected from each treatment ( 80 carcasses) and stored at $4{ }^{\circ} \mathrm{C}$. Three-rib cut samples were collected from each carcass according to Webb et al. (1994) and stored in polyethylene bags at $-20^{\circ} \mathrm{C}$ for dissection and subsequent proximate analysis.

Samples were thawed for 24 hours at $4{ }^{\circ} \mathrm{C}$ before analysis. Samples were dissected into muscle, fat and bone to represent an estimate of the total carcass composition (Webb et al., 1994). Samples of the longissimus lumborum muscle were cut, cooked (Babiker et al., 1990), and cooled overnight for subsequent shear force analysis. Four core samples were taken $(1.27 \mathrm{~cm}$ diameter) parallel with the muscle fibre direction from each sample. Shear force was tested with an Instron apparatus equipped with a WarnerBratzler shear blade. Samples were placed parallel to the blade (Babiker, et al., 1990; Boleman et al., 2004). Each sample was sheared at a speed of $100 \mathrm{~mm} / \mathrm{min}$ and shear force values were recorded in Newton (N). The mean shear force of each sample was calculated and recorded.

The effects of Ralgro and Zilmax on growth performance and carcass characteristics of feedlot lambs were analysed using multifactorial analysis of variance (MANOVA) by the general linear model (GLM) procedure of SAS (2011), which included as factors the steroidal implant type, Zilmax treatment, and Zilmax treatment period. Data were recorded in Microsoft Excel. The growth results during the grower phase, finisher phase, entire growth period, and carcass results were analysed statistically by analysis of covariance and general linear regression models, using the initial weight of the lambs as covariate in the model. All these treatment effects and their interactions were tested at a significance level of $95 \%$ certainty $(P<0.05)$, and differences between treatment means were assessed by Bonferroni's multiple range test.

\section{Results and Discussion}

The effects of Ralgro implants and Zilmax supplementation in the feed and the duration of Zilmax feeding of feedlot lambs are presented in Table 2. Ralgro improved the ADG of SA Mutton Merino lambs during the grower phase $(P<0.05)$, but no significant differences were noted during the finisher phase. Treatment with Zilmax improved the ADG $(P<0.05)$ of the lambs during the finisher phase. It is well known that Zilmax increases the growth rate and ADG in cattle (Hope-Jones et al., 2012; Strydom et al., 2011). Similar results were found by Estrada-Angula et al. (2008), López-Carlos et al. (2011), and López-Carlos et al. (2010), who all reported an increase in ADG in sheep supplemented with Zilmax. Lambs implanted with Ralgro also had significantly higher ADG $(P<0.01)$ compared with lambs that were not implanted. These results are consistent with the literature (Nsahlai et al., 2002; Nold et al., 1992). Nold et al. (1992) reported that Ralgro caused higher live weight gains of sheep owing to an increase in efficiency and not feed intake.

To date there have been no combination studies of the effects of Ralgro and Zilmax in sheep. It is well documented that combinations of steroid implants and Zilmax in cattle produce an additive effect (Baxa et al., 2010; Neill et al., 2009). The results of the current study showed that the effects of the combination of Ralgro and Zilmax on ADG were highly significant $(P<0.01)$ and yielded the highest ADG over the entire feeding period and therefore the best growth rates, which agrees with the results in Baxa et al. (2010) and Neill et al. (2009). The highest ADG was recorded for the treatment group that received Ralgro and Zilmax feed supplementation for 25 days (Figure 1), followed by Ralgro and Zilmax feed supplementation for 18 days (Figure 1). From these results it can be seen that the combined use of Ralgro and Zilmax in lambs yields positive results, especially if Zilmax is fed for 25 days.

The duration of the Zilmax treatment did not affect ADG consistently in sheep that were not implanted with Ralgro. This is probably because $\beta$-agonists cause a rapid growth response at the onset of treatment, but a plateau is often reached because of desensitization of $\beta$-adrenergic receptors (Moody et al., 2000). Growth response over time is not constant with various $\beta$-agonists and different species (López-Carlos et al., 2011). It appears that the combination treatment of Ralgro and Zilmax provides a way to enhance the betaadrenergic agonist effects in lambs, especially at low Zilmax inclusion levels such as those used in this study. 
Table 2 Effects of Ralgro implant, Zilmax feed supplementation and duration of Zilmax feeding on feedlot performance and live weights of SA Mutton Merino lambs

\begin{tabular}{lcccc}
\hline \multirow{2}{*}{$\begin{array}{l}\text { Treatment } \\
(\mathrm{n}=158)\end{array}$} & \multicolumn{3}{c}{$\begin{array}{c}\text { Average daily gains (ADG) } \\
\text { (g/day) }\end{array}$} & $\begin{array}{c}\text { Live weight gain } \\
(\mathrm{kg})\end{array}$ \\
\cline { 2 - 4 } & $\begin{array}{c}\text { Grower phase } \\
\text { (days 1-51) }\end{array}$ & $\begin{array}{c}\text { Finisher phase } \\
\text { (days 51-72 \& 79) }\end{array}$ & $\begin{array}{c}\text { Entire period } \\
\text { (days 1-72 \& 79) }\end{array}$ & \\
\hline
\end{tabular}

\section{Ralgro x Zilmax effects}

$\begin{array}{lllll}\text { Control } & 214.9^{\mathrm{a}} \pm 54.40 & 354.1^{\mathrm{a}} \pm 135.4 & 261.9^{\mathrm{a}} \pm 62.82 & 18.9^{\mathrm{a}} \pm 4.65 \\ \text { Ral } & 233.9^{\mathrm{ab}} \pm 79.45 & 343.9^{\mathrm{a}} \pm 104.7 & 265.6^{\mathrm{a}} \pm 74.01 & 19.3^{\mathrm{a}} \pm 5.49 \\ \text { Zil } & 219.2^{\mathrm{a}} \pm 71.84 & 371.4^{\mathrm{b}} \pm 104.2 & 264.4^{\mathrm{a}} \pm 59.83 & 19.1^{\mathrm{a}} \pm 4.37 \\ \text { Ral }+ \text { Zil } & 278.9^{\mathrm{b}} \pm 61.85 & 370.4^{\mathrm{b}} \pm 115.3 & 306.6^{\mathrm{b}} \pm 63.39 & 22.3^{\mathrm{b}} \pm 5.04\end{array}$

Zilmax feeding period effects

$\begin{array}{lllll}\text { Ral + Zil @ } 18 d & 269.25^{\mathrm{A}} \pm 56.75 & 342.4^{\mathrm{A}} \pm 123.5 & 288.4^{\mathrm{A}} \pm 57.06 & 19.9^{\mathrm{A}} \pm 3.93 \\ \text { Ral + Zil @ } 25 \mathrm{~d} & 287.94^{\mathrm{A}} \pm 66.50 & 397.0^{\mathrm{B}} \pm 103.0 & 323.8^{\mathrm{B}} \pm 65.64 & 24.6^{\mathrm{B}} \pm 4.98\end{array}$

\footnotetext{
${ }^{\mathrm{abc}}$ Means with different superscripts in the same column indicate significant Ralgro $\mathrm{x}$ Zilmax treatment effects $(P<0.05)$

${ }^{\mathrm{AB}}$ Means with different superscripts in the same column indicate significant Zilmax feeding period effects $(P<0.05)$

Ral - Ralgro; Zil - Zilmax
}

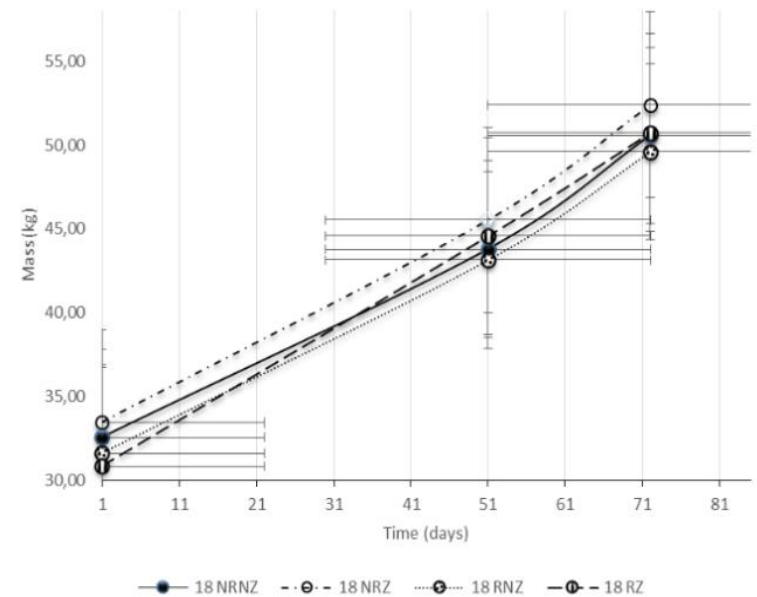

(a)

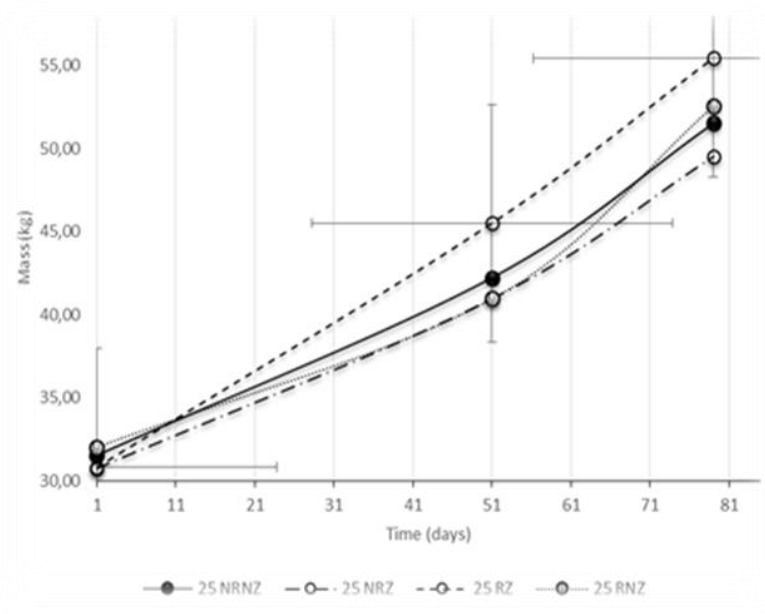

(b)

Figure 1 Effects on growth of SA Mutton Merino lambs of Ralgro implants and Zilmax supplementation in the feed during the finisher period for 18 days (a) or for 25 days (b).

NRNZ - No Ralgro + No Zilmax; NRZ - No Ralgro + Zilmax; RZ - Ralgro + Zilmax; RNZ - Ralgro + No Zilmax

The combination of Ralgro implants and Zilmax feed supplementation increased the cold carcass mass of lambs markedly $(P<0.05)$ compared with those in the other treatment and control groups $($ Table 3$)$. This result agrees with the findings of Neill et al. (2009) in cows fed concentrate diets implanted with Revelor-200 and supplemented with Zilmax. Baxa et al. (2010) also found that Revalor-S and Zilmax had an additive effect on HCW and dressing percentage in cattle.

The improvements in carcass mass reflect the additive effects between steroidal growth implants and Zilmax, which are consistent with the data on the effects of $\beta$-agonists in sheep reported in the literature (Estrada-Angulo et al., 2008; López-Carlos et al., 2011; López-Carlos et al., 2010; Vahedi et al., 2014). The increase in muscle mass is due to the binding of $\beta$-agonists to $\beta$-receptors on the surface of muscle cells, which modifies biochemical processes, causes a decrease in protein degradation and increases protein synthesis (Mersmann, 1998; Eisemann et al., 1993). 
Table 3 Effects of selected carcass parameters in SA Mutton Merino lambs of Ralgro implant, Zilmax feed supplementation and duration of Zilmax feeding for 18 or 25 days

\begin{tabular}{|c|c|c|c|c|c|c|}
\hline $\begin{array}{l}\text { Treatment } \\
(n=80)\end{array}$ & $\begin{array}{l}\text { CCM } \\
(\mathrm{kg})\end{array}$ & Dres.\% & $\begin{array}{l}\text { SCF } \\
(\mathrm{mm})\end{array}$ & $\begin{array}{c}\begin{array}{c}\text { Hide weight } \\
(\mathrm{kg})\end{array} \\
\end{array}$ & $\mathrm{pH}_{45}$ & $\mathrm{pH}_{\mathrm{u}}$ \\
\hline \multicolumn{7}{|c|}{ Ralgro $x$ Zilmax treatment effects } \\
\hline Control & $25.2^{\mathrm{a}} \pm 3.05$ & $48.3^{\mathrm{a}} \pm 4.0$ & $7.4 \pm 2.57$ & $5.4^{\mathrm{a}} \pm 1.17$ & $6.57 \pm 0.18$ & $5.42 \pm 0.10$ \\
\hline Ral & $25.3^{\mathrm{a}} \pm 3.73$ & $48.5^{\mathrm{a}} \pm 3.2$ & $9.0 \pm 3.82$ & $5.2^{\mathrm{a}} \pm 0.77$ & $6.70 \pm 0.31$ & $5.48 \pm 0.07$ \\
\hline Zil & $24.6^{\mathrm{a}} \pm 4.24$ & $49.5^{\mathrm{b}} \pm 2.9$ & $8.4 \pm 4.11$ & $4.7^{\mathrm{b}} \pm 0.77$ & $6.62 \pm 0.40$ & $5.51 \pm 0.19$ \\
\hline Ral + Zil & $26.6^{b} \pm 3.62$ & $49.4^{\mathrm{b}} \pm 2.1$ & $8.1 \pm 2.32$ & $5.1^{\mathrm{a}} \pm 0.73$ & $6.61 \pm 0.26$ & $5.47 \pm 0.15$ \\
\hline \multicolumn{7}{|c|}{ Zilmax feeding period effects } \\
\hline 18 days & $24.8^{A} \pm 2.89$ & $48.4^{\mathrm{A}} \pm 2.2$ & $7.9^{A} \pm 2.50$ & $4.8^{A} \pm 0.39$ & $6.62 \pm 0.33$ & $5.42^{\mathrm{A}} \pm 0.18$ \\
\hline 25 days & $28.7^{\mathrm{B}} \pm 3.35$ & $50.6^{\mathrm{B}} \pm 1.3$ & $8.2^{B} \pm 2.24$ & $5.4^{B} \pm 0.86$ & $6.60 \pm 0.19$ & $5.53^{B} \pm 0.08$ \\
\hline
\end{tabular}

Similarly, Hufstedler et al. (1996) and Hutcheson et al. (1992) reported increased CCM in sheep implanted with Ralgro. However, Nold et al. (1992) argued that Ralgro increased growth rates, but had minimal effects on carcass composition and weight distribution of primal cuts. Salisbury et al. (2007) also found that dressing percentages were unaffected in implanted sheep. The current data indicates a $1 \%$ increase in carcass dressing percentage in sheep fed Zilmax $(P<0.05$; Table 4$)$, while those fed Ralgro alone and those in the control groups were unaffected. This increase in dressing percentage represents an important financial benefit of the use of $\beta$-agonists in sheep. No significant differences were observed in subcutaneous fat thickness or carcass $\mathrm{pH}$ at 45 minutes or 24 hours post mortem among treatment groups. However, lambs fed Zilmax only had significantly lower hide weights $(P<0.05)$, which may be owing to a reduction of fat in the hide because of the lipolytic effects of Zilmax. Similar results were reported in cattle by Scramlin et al. (2010).

Table 4 Effect of Zilmax, Ralgro and duration of Zilmax treatment of feedlot lambs on carcass composition and meat tenderness

\begin{tabular}{|c|c|c|c|}
\hline Treatment $(n=80)$ & Fat (\%) & Muscle (\%) & Shear force $(\mathrm{N})$ \\
\hline \multicolumn{4}{|c|}{ Ralgro $x$ Zilmax treatment effects } \\
\hline Control & $36.0 \pm 5.56$ & $48.7 \pm 4.70$ & $25.7^{\mathrm{a}} \pm 9.16$ \\
\hline Ral & $37.2 \pm 5.57$ & $48.1 \pm 4.89$ & $24.9^{\mathrm{a}} \pm 8.14$ \\
\hline Zil & $36.6 \pm 6.54$ & $48.5 \pm 5.94$ & $36.1^{b} \pm 12.13$ \\
\hline Ral + Zil & $35.5 \pm 4.38$ & $49.7 \pm 3.66$ & $40.9^{b} \pm 14.71$ \\
\hline \multicolumn{4}{|c|}{ Zilmax feeding period effects } \\
\hline ZR18 & $35.0 \pm 4.22$ & $50.6 \pm 3.95$ & $40.6^{b} \pm 15.78$ \\
\hline ZR25 & $35.9 \pm 4.72$ & $48.8 \pm 3.31$ & $41.2^{\mathrm{b}} \pm 14.39$ \\
\hline
\end{tabular}


subcutaneous fat thickness in sheep supplemented with Zilmax (López-Carlos et al., 2010; Vahedi et al., 2014), while others found no difference (Avendaño-Reyers et al., 2011; Estrada-Angulo et al., 2008).

The duration of the Zilmax treatment affected $(P<0.05)$ most carcass parameters, including CCM, dressing percentage, subcutaneous fat thickness, hide weights and ultimate $\mathrm{pH}$ values. Although ultimate $\mathrm{pH}$ values differed statistically, the numerical differences were small. López-Carlos et al. (2011) and Vahedi et al. (2014) showed that CCM increased with longer Zilmax treatment periods. They also showed that a plateau can be reached in the CCM because of down-regulation of $\beta$-adrenergic receptors. However, in the current study the treatment period was probably not long enough to demonstrate this. The best carcass results were obtained by the combination treatment of Ralgro and Zilmax fed for at least 25 days. These results confirmed the additive effects of growth implants followed by Zilmax feed supplementation. The duration of the Zilmax feeding period increased subcutaneous fat thickness $(P<0.05)$. It is well known that concentrated diets fed to animals for extended periods result in higher fat accretion (López-Carlos et al., 2011; Webb \& O'Neill, 2008; Cifuni et al., 2000).

Although it was expected that treatment of lambs with a $\beta$-agonist would affect carcass composition, based on the repartitioning effects of Zilmax, no significant differences were observed. Lambs implanted with Ralgro and treated with Zilmax yielded carcasses that contained about $1 \%$ more muscle, but the differences were not statistically significant. Avendaño-Reyers et al. (2006) found no difference in carcass composition when Zilmax was supplemented in cattle. In contrast, Leheska et al. (2009) and Hilton et al. (2009) reported differences in carcass composition due to Zilmax treatment in sheep. The low effect found in the present study may be due to the low dose of Zilmax, which agrees with the results of Avendaño-Reyers et al. (2006), who used a low dose in cattle.

Ralgro did not affect shear force values of $m$. longissimus lumborum samples, but the use of Zilmax alone or in combination with Ralgro increased shear force values $(P<0.05)$. This increase occurred in all Zilmax treatment groups and was enhanced in lambs treated with both Ralgro implants and Zilmax feed supplementation, especially in lambs supplemented for 25 days. Zilmax is known to adversely affect tenderness in beef (Avendaño-Reyers et al., 2006; Hilton et al., Leheska et al., 2009; Kellermeier et al., 2009; Scramlin et al., 2010; Hope-Jones et al., 2012). To date there have not been reports on tenderness in lamb treated with Zilmax, but the $\beta$-agonist $\mathrm{L}_{644,969}$ has been shown to decrease tenderness in lambs (Pringle et al., 1993). Although the Zilmax treatment increased shear force by about $10 \mathrm{~N}$ in the present study, lamb with shear force values of $40 \mathrm{~N}$ is still regarded as tender meat (Hilton et al., 2009). Therefore, the present results indicate that lambs treated with $40 \mathrm{mg}$ Zilmax per animal per day produced meat that complied with consumer acceptance in terms of tender meat.

\section{Conclusions}

The results suggest that feeding Zilmax in combination with Ralgro implants improves the growth and carcass characteristics of SA Mutton Merino lambs. The combined effects of Ralgro implants and Zilmax supplementation in the feed had additive effects and improved ADG, CCM and dressing percentage, which may hold financial benefits for enterprises with generally low profit margins. Zilmax supplementation decreased the hide weights of lambs. There were no significant changes in fat thickness or carcass composition. Although the shear force of meat samples from carcasses treated with Zilmax was increased, the meat still fell within the norms of tender meat.

\section{Acknowledgements}

The authors wish to thank MSD Animal Health for sponsoring the Ralgro implants and Zilmax feed supplement. Authors are also indebted to Blokhuis Feedlot at Harrismith for their support during the growth trial and Midland Meat for assisting with slaughter and sample collection.

\section{Authors' Contributions}

JA and SDM collected the data and JA drafted the manuscript. ECW designed the study, analysed the data and revised the manuscript. All authors approved the final manuscript.

\section{Conflict of Interest Declaration}

The authors have no financial, personal or other relationships with other people or organisations that could inappropriately influence, or perceived to influence their work. No financial support was received from any source other than the donations of implants and feed additives from MSD Animal Health.

\section{References}

Avendaño-Reyers, L., Macías-Cruz, U., Álvarez-Valenzuela, F.D., Águila-Tepato, E., Torrentera-Olivera, N.G. \& SotoNavarro, S.A., 2011. Effects of zilpaterol hydrochloride on growth performance, carcass characteristics, and wholesale cut yield of hair-breed ewe lambs consuming feedlot diets under moderate environmental conditions. J. Anim. Sci. 89, 4188-4194. 
Avendaño-Reyers, L., Torres-Rodriguez, V., Meraz-Murillo, F.J., Pérez-Linares, C., Figueroa-Saavedra, F. \& Robinson, P.H., 2006. Effects of two $\beta$-adrenergic agonists on finishing performance, carcass characteristics, and meat quality of feedlot steers. J. Anim. Sci. 84, 3259-3265.

Babiker, S.A., El Khider, I.A. \& Shafie, S.A., 1990. Chemical composition and attributes goat meat and lamb. Meat Sci. 28, 273-277.

Baxa, T.J., Hutcheson, J.P., Miller, M.F., Brooks, J.C., Nichols, W.T., Streeter, M.N., Yates, D.A. \& Johnson, B.J., 2010. Additive effects of a steroidal implant and zilpaterol hydrochloride on feedlot performance, carcass characteristics, and skeletal muscle messenger ribonucleic acid abundance in finishing steers. J. Anim. Sci. 88, 330-337.

Boleman, C.T., McKenna, D.R., Ramsey, W.S., Peel, R.K. \& Savell, J.W., 2004. Influence of feeding Vitamin $D_{3}$ and aging on the tenderness of four lamb muscles. Meat Sci. 67, 185-190.

Cifuni, G.F., Napolitano, F., Pacelli, C., Riviezzi, A.M. \& Girolami, A., 2000. Effect of age at slaughter on carcass traits, fatty acid composition and lipid oxidation of Apulian lambs. Small Rumin. Res. 35, 65-70.

Courtheyn, D., Le Bizec, B., Brambilla, G., De Brabander, H.F., Cobbaert, E., Van de Wiele, M., Vercammen, J. \& De Wasch, K., 2002. Recent developments in the use and abuse of growth promoters. Anal. Chim. Acta., 473, 71-82.

Eisemann, J.H. \& Huntington, G.B., 1993. Effects of dietary clenbuterol on net flux across the portal-drained viscera, liver and hindquarters of steers (Bos Taurus). Camp. Biochem. Physiol. 104C (3), 401-406.

Estrada-Angulo, A., Barreras-Serrano, A., Contreras, G., Obregon, J.F., Robles-Estrada, J.C., Plascencia, A. \& Zinn, R.A., 2008. Influence of level of zilpaterol chlorhydrate supplementation on growth performance and carcass characteristics of feedlot lambs. Small Rumin. Res. 80, 107-110.

Hilton, G.G., Montgomery, J.L., Krehbiel, C.R., Yates, D.A., Hutcheson, J.P., Nichols, W.T., Streeter, M.N., Blanton, Jr., J.R. \& Miller, M.F., 2009. Effects of feeding zilpaterol hydrochloride with and without monensin and tylosin on carcass cutability and meat palatability of beef steers. J. Anim. Sci. 87, 1394-1406.

Hope-Jones, M., Strydom, P.E., Frylinck, L. \& Webb, E.C., 2012. Effect of dietary beta-agonist treatment, Vitamin D3 supplementation and electrical stimulation of carcasses on colour and drip loss of steaks from feedlot steers. Meat Sci. 90, 607-612.

Hufstedler, G.D., Gillman, P.L., Carstens, G.E., Greene, L.W. \& Turner, N.D., 1996. Physiological and hormonal responses of lambs repeatedly implanted with Ralgro® and provided two levels of feed intake. J. Anim. Sci. 74, 2376-2384.

Hutcheson, J.P., Greene, L.W., Carstens, G.E. \& Byers, F.M., 1992. Effects of Ralgro® and two dietary levels of calcium and phosphorus on performance, carcass and bone characteristics, and calcium status in growing lambs. J. Anim. Sci. 70, 1346-1351.

Kellermeier, J.D., Tittor, A.W., Brooks, J.C., Gaylean, M.L., Yates, D.A., Hutcheson, J.P., Nichols, W.T., Streeter, M.N., Johnson, B.J. \& Miller, M.F., 2009. Effects of zilpaterol hydrochloride with or without an estrogen-trenbolone acetate terminal implant on carcass traits, retail cutout, tenderness, and muscle fiber diameter in finishing steers. J. Anim. Sci. 87, 3702-3711.

Leheska, J.M., Montgomery, J.L., Krehbiel, C.R., Yates, D.A., Hutcheson, J.P., Nichols, W.T., Streeter, M., Blanton, Jr., J.R. \& Miller, M.F., 2009. Dietary zilpaterol hydrochloride. II. Carcass composition and meat palatability of beef cattle. J. Anim. Sci. 87, 1384-1393.

López-Carlos, M.A., Ramírez, R.G., Aguilera-Soto, J.I., Plascencia, A., Rodríguez, H., Aréchiga, C.F., Rincon, R.M., Medina-Flores, C.A. \& Gutierrez-Bañuelos, H., 2011. Effect of two beta adrenergic agonists and feeding duration on feedlot performance and carcass characteristics of finishing lambs. Livest. Sci. 138, 251-258.

López-Carlos, M.A., Ramírez, R.G., Aguilera-Soto, J.I., Aréchiga, C.F., Méndez-Llorente, F., Rodríguez, H. \& Silva, J.M., 2010. Effect of ractopamine hydrochloride and zilpaterol hydrochloride on growth, diet digestibly, intake and carcass characteristics of feedlot lambs. Livest. Sci. 131, 23-30.

Mersmann, H.J., 1998. Overview of the effects of $\beta$-adrenergic receptor agonists on animal growth including mechanisms of action. J. Anim. Sci. 76, 160-172.

Moody, D.E., Hancock, D.L. \& Anderson, D.B., 2000. Phenethanolamine repartitioning agents. In: J.P.F.D'Mello (ed). Farm animal metabolism and nutrition. CAB International, NY, USA, pp. 65-95.

Neill, S., Unruh, J.A., Marston, T.T., Jaeger, J.R., Hunt, M.C. \& Higgins, J.J., 2009. Effects of implanting and feeding zilpaterol hydrochloride on performance, carcass characteristics, and subprimal beef yields of fed cows. J. Anim. Sci. 87, 704-710.

Nold, R.A., Unruh, J.A., Spaeth, C.W. \& Minton, J.E., 1992. Effect of Ralgro® implant in ram and wether lambs on performance traits, carcass characteristics, and subprimal cut yields and distribution. J. Anim. Sci. 70, 1699-1707.

Nourozi, M., Abazari, M., Raisianzadeh, M., Mohammadi, M. \& ZareShahne, A., 2008. Effect of terbutaline and metaproterenol (two beta-adrenergic agonists) on performance and carcass composition of culled Moghani ewes. Small Rumin. Res. 74, 72-77.

Nsahlai, I.V., Green, H., Bradford, M. \& Bonsi, M.L.K., 2002. The influence of source and level of protein, and implantation with Ralgro® on sheep growth. Livest. Prod. Sci. 74, 103-112.

Perry, T.W., Stob, M., Huber, D.A. \& Peterson, R.C., 1970. Effect of subcutaneous implantation of resorcyclic acid lactone on performance of growing and finishing cattle. J. Anim. Sci. 31, 789-793.

Pringle, T.D., Calkins, C.R., Koohmaraie, M. \& Jones, S.J., 1993. Effects over time of feeding a beta-adrenergic agonist to wether lambs on animal performance, muscle growth, endogenous muscle proteinase activities, and meat tenderness. J. Anim. Sci. 71, 636-644.

Ricks, C.A., Baker, P.K. \& Dalymple, R.H., 1984. Use of repartitioning agents to improve performance and body composition of meat animals. In: Reciprocal Meat Conference Proceedings 37, 5-11. 
Salisbury, M.W., May, B.J., Talley, S.J., Carr, M.A. \& Engdahl, G.R., 2007. Feedlot performance and carcass characteristics of feeder lambs implanted and re-implanted with Ralgro®. Texas J. Agric. and Nat. Res. 20, 1-9.

SAS, 2011. SAS Institute Inc. SAS 9.3 statements: Ref. Cary, North Carolina, USA.

Scramlin, S.M., Platter, W.J., Gomez, R.A., McKeith, Choat, W.J., McKeith, F.K. \& Killefer, J., 2010. Comparative effect of ractopamine hydrochloride and zilpaterol hydrochloride on growth performance, carcass traits, and longissimus tenderness of finishing steers. J. Anim. Sci. 88, 1823-1929.

Sharp, G.D. \& I.A. Dyer. 1971. Effect of Ralgro® on performance and carcass composition of growing-finishing ruminants. J. Anim. Sci. 33, 865.

Strydom, P.E., Hope-Jones, M, Frylinck, L. \& Webb, E.C., 2011. The effects of a beta-agonist treatment, vitamin D3 supplementation and electrical stimulation on meat quality of feedlot steers, Meat Sci. 89, 462-468.

Vahedi, V., Towhidi, A., Zare Shahneh, A., Sadeghi, M., Zamani, F. \& Dunshea, F.R., 2014. Effects of $\beta$-agonist zilpaterol hydrochloride feeding and supplementation period on growth and carcass characteristics of LoriBakhtiari lambs. Small Rumin. Res. 119, 65-71.

Webb, E.C. \& Erasmus, L.J., 2013. The effect of production system and management practices on the quality of meat products from ruminant livestock, S. Afr. J. Anim. Sci. 43(3), 413-423.

Webb, E.C. \& O'Neill, A., 2008. The animal fat paradox and meat quality. Meat Sci. 80, 28-36.

Webb, E.C., Casey, N.H. \& Van Niekerk, W.A., 1994. Fatty acids in the subcutaneous adipose tissue of intensively fed SA Mutton Merino and Dorper wethers. Meat Sci. 38, 123-131. 